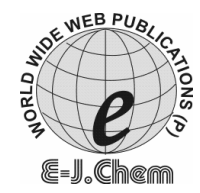

http://www.e-journals.net
ISSN: 0973-4945; CODEN ECJHAO

E-Journal of Chemistry

2009, 6(2), 437-444

\title{
Nutritive Value of Commonly Consumed Bread in Yemen
}

\author{
MOHAMMED S. AL-MUSSALI and MOHSEN A. AL-GAHRI* \\ Food Research and Post Harvest Tech Center -Aden \\ Agricultural Research and Extension Authority-Yemen \\ *Department of Chemistry - Collage of Education / \\ Aden - University of Aden / Yemen \\ mohsen72@hotmail.com
}

Received 5 August 2008; Accepted 1 September 2008

\begin{abstract}
Bread has always been considered as the staple food of choice in Yemen. Because of the paucity of information on the nutritive composition of commonly consumed breads, this study was conducted. Samples were collected randomly from 10 bakeries located in different districts of Aden province, using white wheat and brown wheat flours produced in two different national milling plants located in Aden \& AL-Hoddidah. Fresh crumb moisture, protein, fat, Ash, carbohydrates and energy were analyzed. Minerals such as $\mathrm{Na}, \mathrm{K}, \mathrm{Mg}, \mathrm{Mn}, \mathrm{Fe}$, $\mathrm{Zn}$ and $\mathrm{Cu}$ also determined using flame AAS after wet digestion by conc. nitric acid. The results were analyzed using the statistical program (Genestat-5). The results showed that bakery industry in Yemen does have problems with bread nutritive values especially in protein content and other minerals mainly $\mathrm{K}, \mathrm{Zn}$ and $\mathrm{Cu}$ that are important for health to Yemeni consumer.
\end{abstract}

Keywords: Bread, Nutritive value, Bakeries, Yemen

\section{Introduction}

Bread is an essential food in human nutrition. It is a good source of energy and contains groups of vitamin B, proteins and minerals which are essential in our diet ${ }^{1}$. In Yemen, bread is consumed at higher ratios than other countries. It is reported that the amount of daily consumption ranged from 250-320 g per capita according to the imported quality of wheat ${ }^{2}$. Yemen imports annually about $90 \%$ of its needs of wheat grains mainly for bread making and other bakery products. Milling of wheat grains took place in a local national milling plants situated in Aden (commercial capital of Rep. of Yemen) an international well known seaport as well as in another city which is considered the next seaport of Yemen (AL-Hoddidah). 
There are mainly five milling plants with a milling daily total capacity of about $7000 \mathrm{Mt}$ of grains producing about $90 \%$ of their production white wheat flour with about $75 \%$ of extraction rate. There are several kinds of bread produced in Yemen. The most commonly consumed bread in Aden, AL-Hoddidah and other governorates throughout the country are pan bread, French type bread, flat bread, sliced bread (produced in bakeries) and the fifth one produced in a public restaurants using earthen ovens for baking it which is named (Mulwah) a flat unleavened bread with a diameter ranged from $30-50 \mathrm{~cm}$.

Bread is present at the table during all three main meals of the day as a main diet consumed either with fish, meat, mixed vegetables and legumes by the majority of Yemen people and present twice in few governorates, that used rice as a third meal, especially whose living in the coastal regions of the country. White wheat flour with about $90 \%$ is used for bread making of different kinds of bread in Yemen.

The milling process removes many important nutrients when white wheat flour in produced. As a result of milling the palatability is increased but the nutritional value of the product is decreased ${ }^{3}$.The nutritive value of bread could be increased if, for example wheat bran is incorporated into bread formula ${ }^{4}$.

Bread is a food product that is universally accepted as a very convenient form of food that has desirability to all population rich and poor, rural and urban. It is a good source of nutrients, such as macronutrients (carbohydrates, protein and fat) and micronutrients (minerals and vitamins that are all essential for human health. This lead all countries throughout the world to study the composition of the bread that consumed to improve it's nutritive value.

Alian et $a l^{5}$ determined the chemical content of balady and pan bread made of whole wheat flour and with flour of $72 \%$ extraction rate. They concluded in their results that balady bread contains moisture (33-34\%), protein (11.8-11.9\%), fat (2.53-2.55\%), crude fiber (3.62$3.93 \%)$, ash (2.63-2.98\%) and carbohydrate (78.91-78.98\%). This is produced from whole wheat flour, but these nutrients obtained from white wheat flour of $72 \%$ extraction were on the range of (32-33\%) of moisture, (11.58-11.65\%) of protein, (1.4-1.6\%) of fat, $(0.87-0.95 \%)$ of crude fiber, (1.67-1.81\%) of ash and (84.1-84.2\%) of carbohydrates.

As far as pan bread is concerned, the same team found that, this kind of bread had moisture content ranged from (25.5-24.7\%), protein (11.78-11.91\%), fat (3.56-3.61\%) crude fiber $(3.58-3.82 \%)$, ash (1.95-2.38\%) and carbohydrate $(78.65-78.74 \%)$ that produced from whole wheat flour. At the same time levels of white wheat flour of $72 \%$ extraction were ranged from $(24.1-24.69 \%)$ of moisture $(11.55-11.62 \%)$ of protein, $(2.35-2.49 \%)$ of fat, $(0.89-1.29 \%)$ of ash and (83.7-83.9\%) of carbohydrates.

The micronutrients analyzed for the same study for balady bread were ranged from (3.5$4.1 \mathrm{mg} / 100 \mathrm{~g})$ of $\mathrm{Mn},(167-1751 \mathrm{mg} / 100 \mathrm{~g})$ of Mg, $(2.20-3.041 \mathrm{mg} / 100 \mathrm{~g})$ of Zinc, $(0.49-0.561$ $\mathrm{mg} / 100 \mathrm{~g})$ of $\mathrm{Cu},(30-321 \mathrm{mg} / 100 \mathrm{~g})$ of $\mathrm{Ca}$ and $(310-3401 \mathrm{mg} / 100 \mathrm{~g})$ of phosphorus which were made from whole wheat flour, but the same nutrients were on the range of (2.25-2.51 $\mathrm{mg} / 100 \mathrm{~g})$ of Mn, (126-1421 mg/100 g) of Mg, (1.58-2.101 mg/100 g) of Zinc, (0.42-0.421 $\mathrm{mg} / 100 \mathrm{~g})$ of $\mathrm{Cu},(21-221 \mathrm{mg} / 100 \mathrm{~g})$ of $\mathrm{Ca}$ and $(190-2201 \mathrm{mg} / 100 \mathrm{~g})$ of phosphorus for the same balady bread made of white wheat flour of $72 \%$ extraction. On the other hand those micronutrients were found to be $(2.89-3.041 \mathrm{mg} / 100 \mathrm{~g})$ of $\mathrm{Mn},(110-1301 \mathrm{mg} / 100 \mathrm{~g}) \mathrm{of} \mathrm{Mg}$, $(2.4-3.91 \mathrm{mg} / 100 \mathrm{~g})$ of $\mathrm{Zn},(0.4-0.61 \mathrm{mg} / 100 \mathrm{~g})$ of $\mathrm{Cu},(22-251 \mathrm{mg} / 100 \mathrm{~g})$ of $\mathrm{Ca}$ and $(298-$ $3101 \mathrm{mg} / 100 \mathrm{~g}$ ) of phosphorus in pan bread produced of whole wheat flour. At the same time those nutrients were on the range of $(1.93-2.071 \mathrm{mg} / 100 \mathrm{~g})$ of $\mathrm{Mn},(110-1051 \mathrm{mg} / 100 \mathrm{~g})$ of $\mathrm{Mg},(2.10-2.721 \mathrm{mg} / 100 \mathrm{~g})$ of $\mathrm{Zn},(0.25-0.31 \mathrm{mg} / 100 \mathrm{~g})$ of $\mathrm{Cu},(15-191 \mathrm{mg} / 100 \mathrm{~g})$ of $\mathrm{Ca}$, 
$(185-1961 \mathrm{mg} / 100 \mathrm{~g})$ of phosphorus in pan bread but produced from white wheat flour of $72 \%$ extraction.

Hussein $e t a l^{6}$ also studied the macro and micronutrients (minerals) in pan bread from white wheat flour of $72 \%$ extraction. The study showed that the micronutrients, protein, fat, fiber, ash, carbohydrate and moisture were $10.63 \%, 2.67 \%, 0.6 \%, 0.64 \%, 79.04 \%$ and $6.42 \%$ respectively. Those values were increased when partial replacement of wheat flour with $15 \%$ of wheat germ was used, so the contents increased to be 14.20 (protein), $2.95 \%$ (fat), $0.91 \%$ (fiber), $1.26 \%$ (ash), $74.01 \%$ (carbohydrate) and $6.67 \%$ for moisture. As far as mineral contents are concerned, they were stated for $\mathrm{Na}(217.4 \mathrm{mg} / 100 \mathrm{~g}) \mathrm{K}(134.51$ $\mathrm{mg} / 100 \mathrm{~g}), \mathrm{Mg}(128.21 \mathrm{mg} / 100 \mathrm{~g}), \mathrm{Mn}(1.901 \mathrm{mg} / 100 \mathrm{~g}), \mathrm{Cu}(0.351 \mathrm{mg} / 100 \mathrm{~g}), \mathrm{Zn}(0.61$ $\mathrm{mg} / 100 \mathrm{~g}), \mathrm{Ca}(27.91 \mathrm{mg} / 100 \mathrm{~g})$ and $\mathrm{Fe}(1.121 \mathrm{mg} / 100 \mathrm{~g})$. With additional of wheat germ, the contents were stated as such $224.61 \mathrm{mg} / 100 \mathrm{~g}$ of Na, $195.71 \mathrm{mg} / 100 \mathrm{~g}$ of K, 181.81 $\mathrm{mg} / 100 \mathrm{~g}$ of $\mathrm{Mg}, 5.801 \mathrm{mg} / 100 \mathrm{~g}$ of $\mathrm{Mn}, 0.561 \mathrm{mg} / 100 \mathrm{~g}$ of $\mathrm{Cu}, 2.901 \mathrm{mg} / 100 \mathrm{~g}$ of $\mathrm{Zn}$, $40.71 \mathrm{mg} / 100 \mathrm{~g}$ of $\mathrm{Ca}$ and $5.291 \mathrm{mg} / 100 \mathrm{~g}$ of Fe.

Ebuehi et $a l^{7}$ determined a mineral concentrations in a part of their study for the most consumed bread in Nigeria. The mineral concentration were ranged from $548-2006 \mathrm{mg} / 100 \mathrm{~g}$ of $\mathrm{Na}, 55-305 \mathrm{mg} / 100 \mathrm{~g}$ of Mg, 0.9-6.5 mg/100 g of Mn, 41-224 mg/100 g of K, 94-190 mg/100 g of $\mathrm{Ca}, 0.04-1 \mathrm{mg} / 100 \mathrm{~g}$ of $\mathrm{Cu}, 0.3-65 \mathrm{mg} / 100 \mathrm{~g}$ of $\mathrm{Zn}$ and $0.2-5.3 \mathrm{mg} / 100 \mathrm{~g}$ of $\mathrm{Fe}$. In the study of B.Demirozu et $a l^{8}$ who determined some metals in Turkey bread, reported the concentrations of iron, copper and zinc in 120 bread samples analyzed were 19.2, 22.1 and $10.0 \mathrm{mg} / \mathrm{kg}$ respectively.

Al-Kanhal et $a l^{9}$ studied the nutritive value of various breads in Saudi Arabia, such as Mafroud, Samouli (French type bread) and white sliced loaf commonly consumed all over the country. They concluded that Mafroud, Samouli and white sliced loaf had moisture $(26.4 \%, 32.1 \%, 34.5 \%)$, Protein $(9.4 \%, 8.7 \%, 8.8 \%)$, fat $(0.9 \%, 1.4 \%, 2.4 \%)$, fiber $(2.1 \%, 2.7 \%, 1.9 \%)$, Ash $(0.6 \%, 0.7 \%, 1.8 \%)$, Carbohydrates $(60.6 \%, 54.8 \%, 50.7 \%)$ and total energy $(288,267,260 \mathrm{Kcal} / 100 \mathrm{~g})$ respectively. The mineral contents of those types of bread were $(2.2,2.4,12.5 \mathrm{mg} / 100 \mathrm{~g})$ for Calcium, $(41.9,320.8,75.8 \mathrm{mg} / 100 \mathrm{~g})$ for phosphorus, $(207.7,304.3,274.5 \mathrm{mg} / 100 \mathrm{~g})$ for Sodium, $(67.2,101.4,89.4 \mathrm{mg} / 100 \mathrm{~g})$ for potassium, $(1.9,1.7,2.6 \mathrm{mg} / 100 \mathrm{~g})$ for iron respectively.

There is paucity of information on the nutritive composition of breads produced in Yemen. Therefore, the objective of this study is to determine the macronutrients and minerals available in the main popularly breads commonly consumed all over the country, produced from wheat grains milled locally from the well known national milling plants located in different main cities and their products distributed throughout the country.

\section{Experimental}

\section{Sampling}

Breads were collected randomly from 10 bakeries located in different district of Aden. Five of them using wheat flour produced in the Red Sea milling plant located at Al-Hodedah city (450 km from Aden). The remaining five bakeries used wheat flour produced in a milling plant in Aden (Yemen Milling Company). Two codes were given according to the type of wheat flour used. A for AL-Hodidah and B for Aden, and different kind of bread were purchased of 5 pieces for each one. The dough of public bread (Mulwah) was prepared in FRPHC (Food Research \& Post harvest Technology Centre) with $10 \%$ wheat bran and the other without wheat bran the codes are $\mathrm{C}_{2}$ and $\mathrm{C}_{1}$ respectively. The dough was baked in a public restaurant. Below is the bread brand with their codes. 


$\begin{array}{lllll}\mathrm{A}_{1} & \text { White Flat Bread } & \text { Mufroud } & \mathrm{A}_{4} & \text { French Bread } \\ \mathrm{B}_{1} & \text { White Flat Bread } & & \mathrm{B}_{4} & \text { French Bread } \\ \mathrm{A}_{2} & \text { Brown Flat Bread } & & \mathrm{A}_{5} & \text { White Sliced Loaf } \\ \mathrm{B}_{2} & \text { Brown Flat Bread } & & \mathrm{B}_{5} & \text { White sliced Loaf } \\ \mathrm{A}_{3} & \text { Pan Bread } & \mathrm{C} 1 & \text { AL-Mulwah Bread } \\ \mathrm{B}_{3} & \text { Pan Bread } & \mathrm{C} 2 & \text { Al-Mulwah Bran Bread } & \end{array}$

Moisture content of different kinds of breads was determined after 1-2 $\mathrm{h}$ of baking using Halogen Infrared Analytical Balance Analyzer (AMB-310).

\section{Preparation of the samples for macronutrients analysis}

Bread pieces of each sample cut into small and spread on papers for drying at room temperature for $15-20 \mathrm{~h}$ till to be easy for grinding in a coffee grinder, so that the ground materials can pass through a sieve No.20. The thorough dried again in an air oven at $130^{\circ} \mathrm{C}$ for an $\mathrm{h}$. The dried materials were kept in plastic bottles ready for chemical analysis a dry basis. Protein (NX5-7), fat, ash, fiber were determine as stated by (Anan \& Yousef, 1996) ${ }^{10}$. Carbohydrates were calculated by difference. Energy content was calculated by multiplying the protein, fat and carbohydrates by factors of 4 , 9 and 4 respectively.

\section{Minerals determination}

The concentration of selected minerals in the bread samples (brands), such as $\mathrm{Na}, \mathrm{K}, \mathrm{Mn}$, $\mathrm{Mg}, \mathrm{Zn}, \mathrm{Cu}$ and $\mathrm{Fe}$ were determined using Flame Atomic Absorption Spectrophotometervario-6. The minerals were estimated after wet digestion of $5 \mathrm{~g}$ sample using concentrated $\mathrm{HNO}_{3}$ and perchloric acid, as described by Anan \& Yousef ${ }^{10}$.

\section{Statistical analysis}

Statistical analysis was conducted using Genestat-5 software.

\section{Results and Discussion}

The proximate composition and mineral contents of various breads are given in the Tables 1 and 2.

Table 1. The proximate composition of various breads.

\begin{tabular}{ccccccc}
\hline $\begin{array}{c}\text { Samples } \\
\text { Codes }\end{array}$ & $\begin{array}{c}\text { Moisture } \\
\%\end{array}$ & $\begin{array}{c}\text { Protein } \\
\%\end{array}$ & Fat $\%$ & Ash $\%$ & $\begin{array}{c}\text { Carbohydrate } \\
\%\end{array}$ & $\begin{array}{c}\text { Energy } \\
\text { Kcal } / 100 \mathrm{~g}\end{array}$ \\
\hline A1 & $29.0 \mathrm{f}$ & $11.021 \mathrm{c}$ & $0.52 \mathrm{e}$ & $0.81 \mathrm{fg}$ & $58.649 \mathrm{~b}$ & $283.36 \mathrm{c}$ \\
B1 & $28.5 \mathrm{f}$ & $10.709 \mathrm{~d}$ & $0.71 \mathrm{de}$ & $0.88 \mathrm{f}$ & $59.201 \mathrm{a}$ & $286.03 \mathrm{~d}$ \\
A2 & $28.0 \mathrm{~g}$ & $11.407 \mathrm{a}$ & $1.00 \mathrm{de}$ & $1.58 \mathrm{c}$ & $58.013 \mathrm{c}$ & $286.68 \mathrm{~d}$ \\
B2 & $28.0 \mathrm{~g}$ & $11.360 \mathrm{a}$ & $1.15 \mathrm{~d}$ & $1.68 \mathrm{~b}$ & $57.810 \mathrm{c}$ & $287.03 \mathrm{~d}$ \\
A3 & $32.4 \mathrm{~d}$ & $11.255 \mathrm{~b}$ & $1.83 \mathrm{c}$ & $0.79 \mathrm{fg}$ & $53.625 \mathrm{f}$ & $275.99 \mathrm{f}$ \\
B3 & $33 \mathrm{~cd}$ & $11.278 \mathrm{~b}$ & $0.67 \mathrm{de}$ & $0.88 \mathrm{f}$ & $54.172 \mathrm{e}$ & $267.83 \mathrm{~g}$ \\
A4 & $33.2 \mathrm{bcd}$ & $11.284 \mathrm{~b}$ & $0.48 \mathrm{e}$ & $0.86 \mathrm{f}$ & $53.676 \mathrm{f}$ & $264.16 \mathrm{~h}$ \\
B4 & $33.5 \mathrm{bc}$ & $10.499 \mathrm{e}$ & $0.59 \mathrm{de}$ & $0.89 \mathrm{f}$ & $54.521 \mathrm{e}$ & $265.39 \mathrm{~h}$ \\
A5 & $34.6 \mathrm{a}$ & $10.369 \mathrm{f}$ & $3.96 \mathrm{a}$ & $0.76 \mathrm{~g}$ & $50.311 \mathrm{~h}$ & $278.36 \mathrm{e}$ \\
B5 & $34.1 \mathrm{ab}$ & $10.501 \mathrm{e}$ & $2.75 \mathrm{~b}$ & $1.08 \mathrm{~d}$ & $51.569 \mathrm{~g}$ & $273.03 \mathrm{i}$ \\
C1 & $28.4 \mathrm{fg}$ & $9.987 \mathrm{~g}$ & $3.92 \mathrm{a}$ & $0.98 \mathrm{e}$ & $56.713 \mathrm{~d}$ & $302.08 \mathrm{a}$ \\
C2 & $30.0 \mathrm{e}$ & $11.390 \mathrm{a}$ & $4.17 \mathrm{a}$ & $2.64 \mathrm{a}$ & $51.800 \mathrm{~g}$ & $290.29 \mathrm{~b}$ \\
LSD $(0.05)$ & 0.85 & 0.128 & 0.55 & 0.08 & 0.396 & 1.822 \\
\hline
\end{tabular}

* Means within a column followed by a different letter are significantly different $(P<0.05)$. 
Table 2. The mineral contents of various breads.

\begin{tabular}{cllllllll}
\hline Samples Codes & \multicolumn{1}{c}{$\mathrm{Na}$} & \multicolumn{1}{c}{$\mathrm{K}$} & \multicolumn{1}{c}{$\mathrm{Mg}$} & \multicolumn{1}{c}{$\mathrm{Mn}$} & \multicolumn{1}{c}{$\mathrm{Cu}$} & $\mathrm{Fe}$ & \multicolumn{1}{c}{$\mathrm{Zn}$} \\
\hline A1 & $58.16 \mathrm{f}$ & $105.39 \mathrm{c}$ & $30.25 \mathrm{f}$ & $0.546 \mathrm{de}$ & $0.158 \mathrm{~d}$ & $2.75 \mathrm{e}$ & $0.890 \mathrm{ef}$ \\
$\mathrm{B} 1$ & $69.48 \mathrm{f}$ & $108.06 \mathrm{c}$ & $47.36 \mathrm{~cd}$ & $0.524 \mathrm{de}$ & $0.128 \mathrm{e}$ & $2.05 \mathrm{f}$ & $1.070 \mathrm{~d}$ \\
$\mathrm{~A} 2$ & $135 \mathrm{de}$ & $227.17 \mathrm{a}$ & $57.46 \mathrm{~b}$ & $2.269 \mathrm{~b}$ & $0.287 \mathrm{a}$ & $7.29 \mathrm{~b}$ & $1.460 \mathrm{~b}$ \\
B2 & $122.92 \mathrm{de}$ & $222.24 \mathrm{a}$ & $74.42 \mathrm{a}$ & $2.945 \mathrm{a}$ & $0.278 \mathrm{ab}$ & $6.76 \mathrm{c}$ & $2.040 \mathrm{a}$ \\
A3 & $140.64 \mathrm{~d}$ & $105.98 \mathrm{c}$ & $38.14 \mathrm{e}$ & $0.393 \mathrm{de}$ & $0.206 \mathrm{c}$ & $7.08 \mathrm{bc}$ & $0.816 \mathrm{f}$ \\
B3 & $62.41 \mathrm{f}$ & $97.28 \mathrm{~d}$ & $36.94 \mathrm{e}$ & $0.385 \mathrm{de}$ & $0.219 \mathrm{c}$ & $6.85 \mathrm{c}$ & $0.895 \mathrm{ef}$ \\
A4 & $148.52 \mathrm{~cd}$ & $105.36 \mathrm{c}$ & 38.12 & $0.486 \mathrm{de}$ & $0.208 \mathrm{c}$ & $7.82 \mathrm{a}$ & $0.806 \mathrm{f}$ \\
B4 & $173.2 \mathrm{c}$ & $104.18 \mathrm{~cd}$ & $50.80 \mathrm{c}$ & $0.490 \mathrm{de}$ & $0.267 \mathrm{~b}$ & $5.67 \mathrm{~d}$ & $1.309 \mathrm{c}$ \\
A5 & $114.04 \mathrm{e}$ & $101.80 \mathrm{~cd}$ & $35.99 \mathrm{e}$ & $0.572 \mathrm{~d}$ & $0.134 \mathrm{e}$ & $7.29 \mathrm{~b}$ & $0.778 \mathrm{f}$ \\
B5 & $173.48 \mathrm{c}$ & $107.18 \mathrm{c}$ & $46.24 \mathrm{~d}$ & $0.444 \mathrm{de}$ & $0.120 \mathrm{e}$ & $7.01 \mathrm{bc}$ & $1.290 \mathrm{c}$ \\
C1 & $479.2 \mathrm{~b}$ & $97.56 \mathrm{~d}$ & $34.81 \mathrm{e}$ & $0.300 \mathrm{e}$ & $0.146 \mathrm{de}$ & $1.99 \mathrm{de}$ & $0.920 \mathrm{e}$ \\
C2 & $555.6 \mathrm{a}$ & $161.24 \mathrm{~b}$ & $47.04 \mathrm{~cd}$ & $1.357 \mathrm{c}$ & $0.211 \mathrm{c}$ & $7.67 \mathrm{a}$ & $1.489 \mathrm{~b}$ \\
$\mathrm{LSD}(0.05)$ & 26.33 & 6.84 & 4.54 & 0.256 & 0.016 & 0.376 & 0.091 \\
\hline
\end{tabular}

* Means within a column followed by a different letter are significantly different $(P<0.05)$.

\section{The moisture}

Moisture content of foods is usually used as an indicator of food quality. It is important to measure the moisture content in breads because of it's potential impact on the sensory, physical and microbial properties of the bread ${ }^{11}$. Ideal moisture content has been reported to positively increase loaf volume of breads ${ }^{12}$.

For consumers, loaf volume is an important sensory attributes mainly in pan bread, sliced bread and French type bread (Samouli), that is why those types having high content of moisture compared to flat bread that usually had greater surface area which facilitate more moisture loss during baking and cooling. Refer to the Table 1, the moisture content of those types of breads that had more crumb, ranged from 32-34\% such as pan bread, sliced bread - French type bread. Barcenans and Rosell ${ }^{13}$ reported, moisture content ranging from 35.3-36.5\% for such kind of breads. The observed difference in moisture content may be due to presence of different components as well as the heating techniques and heating rate used during baking. The moisture contents of the all kind of flat bread of this study ranged from 28-29\%. These results are agreed with the result of Sidhu et al. ${ }^{14}$ who reported that the moisture content of flat Arabic white bread ranged from 28.3-29.9\%.

\section{Protein}

The protein quantity and quality of bread depend on variety and the extraction rate of flour used. The results shows that (Table 1), the protein content in the breads (A2,B2) made of brown flour (Extraction rate 85-95\%) differ significantly in this nutrient with all other bread kinds except with that public flat bread (Mulawah) which contain 10\% wheat bran in it's dough that increase it's protein content. Though the protein content of all kinds of Yemeni bread under study are high comparatively with the same kind of Saudi breads reported by Al-kanhal et al. ${ }^{9}$ but approximately with the same content of protein of balady and pan breads reported by Alian et al. ${ }^{5}$ \& Hussein et $a l .{ }^{6}$, consumed in Egypt. After all the protein content of flat bread (Mufroud) prepared from brown wheat flour should contain protein content not less than $12 \%$ as well as pan and sliced bread should contain protein content not less than $11 \%$ according to Yemeni standards of bread (specification No.2001/160) such status clarify that the protein content of imported wheat grain are originally with low content, 
since with the addition of $10 \%$ wheat bran to white wheat flour could not provide the bread it's protein content to fulfill the condition of local specification.

\section{Fat}

The fat content, depending on addition of fat in the preparation of dough was highest in Mulawah bread (3.92-4.17\%) $\mathrm{C} 1$ and $\mathrm{C} 2$ as well as sliced bread A5 with 3.39\% that are significantly different with the remaining bread types. The majority of Yemeni bakeries did not add fat in mix of bread dough, to reduce the cost of bread making as the bakers stated ${ }^{15}$.In case Mulawah bread that mainly produced in public restaurants, oil is adding during preparation of each dough piece before baking. Fat content of similar kinds of bread reported ${ }^{5,6,9}$ are higher than those of Yemeni bread mentioned in the study with the exception of sliced and Mulawah bread.

\section{Ash}

Typical wheat has an ash (minerals) content of about 1.5\%. However, the ash is not distributed evenly in the grain. The inner endosperm may only contain $0.3 \%$ where as the bran may contain $6 \%$. The content of ash in wheat flour is an indication of it's extraction rate $^{3}$. The contents of ash in all kinds of bread ranged from $0.76-0.98 \%$,but those which produced from brown bread (A2,B2) had ash content ranged from 1.58- 1.68\%.Only Mulawah bread had an ash content reached to $2.64 \%$ which differ significantly with other kinds. This increase may be due to the present of bran in it's mix.

\section{Carbohydrate}

Bread is a one of the most important source of carbohydrate in the form of starch, which is the most abundant polysaccharide and a major food reserve providing a bulk nutrient and energy source on the human diet ${ }^{16}$.

Carbohydrate varied from $50.31 \%$ (A5) to $59.2 \%$ (B1) which is significantly different from all other types of bread. This increase may be due to the lower content of moisture that raised the content of carbohydrate which is calculated by difference. This type of bread (flat bread) is characterized by lower moisture content compared to other bread that have high amount of crumb.

\section{Energy}

The importance of a food item depends upon how much of energy that can provide to a person when it is consumed by him/her. Referring to the Table No.1, the energy ranged from 264.16 to $302.08 \mathrm{kcal} / 100 \mathrm{~g}$ for pan bread (A4) and Mulawah bread (C1) respectively. The average energy for all commonly used bread stated in the sample table is about $280 \mathrm{kcal} / 100 \mathrm{~g}$ of bread.

The average daily per capita energy for Yemeni population has been reported to be 2119 $\mathrm{kcal}^{17}$. Based on the average consumption ( $\left.285 \mathrm{~g} / \mathrm{head} / \mathrm{day}\right)$ of bread for the last five years ${ }^{18}$, wheat bread can meet $37.6 \%$ of energy requirements at national level per person per day.

\section{Minerals}

The mineral composition data (Table 2) showed that, sodium content in all kinds of bread ranged from $58.16-555.6 \mathrm{mg} / 100 \mathrm{~g}$. Mulwah with $10 \%$ of bran content $(\mathrm{C} 2)$ contain the higher quantity of $\mathrm{Na}$ which may not be suitable for hypertensive individuals. Similar results in breads made of white wheat flour with sodium content of $217 \mathrm{mg} / 100 \mathrm{~g}, 548 \mathrm{mg} / 100 \mathrm{~g}$ and content of 207-304 mg/100 g respectively as reported ${ }^{6,7,9}$. Bread with reduced sodium has been marketed helps to maintain a healthy heart and circulation ${ }^{19}$. A maximum level of $120 \mathrm{mg} / 100 \mathrm{~g}$ bread is allowed ${ }^{20}$. Breads coded (A1, B1, B2, B3, A5) had reasonable content of sodium. 
The variation of sodium content in the breads under study may be due to the addition of salt of different quantity in the local bakeries. Highest quantities of potassium were found in the bread A2-B2 that produced from brown wheat flour with a concentration of $222-227 \mathrm{mg} / 100 \mathrm{~g}$.

Brown flat bread (A2-B2) named (Mufroud) had the highest content of $\mathrm{Mg}$ (57.46,74.42 $\mathrm{mg} / 100 \mathrm{~g}$ ), B2 with $74.42 \mathrm{mg} / 100 \mathrm{~g}$ differ significantly with all types of bread even with A2 as well which indicates the different extraction rate of brown flours from different milling plants. Similar results in the same types of bread reported ${ }^{5-7}$ had $\mathrm{Mg}$ in the range of $110-130 \mathrm{mg} / 100 \mathrm{~g}$, $128.2 \mathrm{mg} / 100 \mathrm{~g}$ and $55-305 \mathrm{mg} / 100 \mathrm{~g}$ respectively. These results showed that, this mineral is with lower content in almost all of Yemeni bread under study. On the same pattern the same types of bread (A2, B2) had the highest contents of Mn (2.269-2.945 mg/100 g) for both of them and B2 differ significantly with all other breads. Majority of Yemeni bread had content of Mn ranged from $0.3-0.5 \mathrm{mg} / 100 \mathrm{~g}$ because they are made of white wheat flour with an extraction rate of $72-76 \%$.

Majority of Yemeni bread that reported on the Table 2 had the highest amount of Fe $(7.6-5.6 \mathrm{mg} / 100 \mathrm{~g})$. This increase is due to the fortification of wheat flour with $\mathrm{Fe}$ by Government rules and regulations. Saudi breads (Mufroud, Samouli and white sliced loaf) had iron ranged from 1.6-2.7 mg/100 g as reported by AL-kanhal et al. ${ }^{9}$

Zinc and copper are also essential elements for human body and they result in chronic and acute effects in case of their deficiency. As reported by the Food, World and Agricultural Organization, United Nations and World Health Organization recommended dietary allowances (RDA) of zinc ranged from $15-12 \mathrm{mg}^{21}$.

Those breads under study contain zinc ranged $0.77-2.0 \mathrm{mg} / 100 \mathrm{~g}$ that provides from $14.6-38 \%$ of zinc to Yemeni consumer according to its averaged daily consumption of bread. In case of copper its content in all types of bread ranged from $0.12-0.28 \mathrm{mg} / 100 \mathrm{~g}$. The high concentration was found in the brown flat bread which it's consumption is very low all over the country. Results reported by Alian, Hussein in pan bread produced from whole wheat flour and white wheat flour has copper ranged from 0.4-0.6 and 0.35 mg/100 g respectively.

The results from the study showed that bakery industry in Yemen does have problems with bread nutritive values especially in protein and other minerals that are important for health to Yemeni consumers. The output of this work will force Yemeni researchers to work on how to improve the quality of Yemeni breads.

\section{References}

1. Dewettinck K, Van Bockstaele F, B.kuhne, Van de Walle D, Courtens T.M and Gellynek X, J Cereal Sci., 2008, 10, 1-15.

2. AL-Mussali M S, Yemen J Agricultural Research and Studies, 2004, 11, 26-39.

3. Hoseney Carl R, Principles of cereal science and technology American Association of Cereal Chemists, Inc U.S.A, 1986.

4. AL-Mussali M S, Basunbel F and Khamees H, Yemen J Agricultural Research and Studies, 2007, 16, 5-18.

5. Alian A M, Abdel-latif A R and Yaseen A A E, Egypt J Food Sci., 1997, 25,121-138.

6. Hussein N M,.Studies on improving the nutritional value of some types of bread, Ph D Thesis, Faculty of Agri., Cairo-University, Egypt, 2001. 
7. Ebuehi O A T O, Owolabi C C, Ikanone, Amabib I T and Ajekewu A P, Nigerian Food J., 2007, 25, 2, 95-100.

8. Demirozut B,.Saldamli I, Gursel B, Ucak A, Cetinyokus F and Yuzbas N, J Cereal Sci., 2003, 37, 171-177.

9. AL-Kanhal M A, AL-Mohizea I S, AL-Othaimeen A I and Akmal Khan M, Int $J$ Food Sci Nutr., 1999, 50, 345-349.

10. Aman M B and Yousef M M, Chemistry \& Food Analysis, Bookshop New Alexandria,Egypt, 1996.

11. Hathorn C S, Biswas M A, Gichuhi P N and Bovell A C, Benjamin LebensmittelWissenschaft und-Technologie, 2008, 41, 803-815.

12. Gallagher E, Gormley T R and Arendt E K, J Food Eng., 2003, 56, 156-161.

13. Barcenas M E and Rosell C M, Food Chemistry, 2006, 95, 438-445.

14. Sidhu, Jiwan S, Saud N, AL-Hooti, Jameela and M.AL-Saqar, Food Chemistry, 1999, 67, 365-371.

15. AL-Mussali M S, Evaluation of Breadmaking Industry in Yemen. $4^{\text {th }}$ Scientific Sympossium for breadday: Present and Future of Breadmaking in Yemen.Ministry of Trade \& Industry/Agricultural Reseach \& Extention Authority-16 July, Sanna.Yemen, 2004.

16 Shelton D R, Lee W J, Cereal Carbohydrates In: Kulp K, Ponter Jr, J G (Ed.). Handbook of Cereal Science and Technology. $2^{\text {nd }}$ Ed., Marcel DeKkerInc, New York, 2000, pp385-416.

17. UNDP/Central Statistic Department-Yemen, Technical report/Food Basket in Yemen on the basis of per capita requirement of energy, Sanna, Yemen, 1999.

18 AL-Mussali, Basunbel M.S F and Hassan Derbass Bread from Composite Flour of Wheat and Millet.Tecnical report, Food Research \& Postharvest Tecnology Centre Agri Reseach \& Extention Authority, Yemen, 2007.

19. Young J, Food Industry J., 2001, 4, 136-144.

20 Meuser F, Brummer J M and Seibel W, Cereal Foods World, 1994, 39, 222-230.

21 Welch R M and Graham R D, J Exp Bot., 2004, 55, 353-364. 


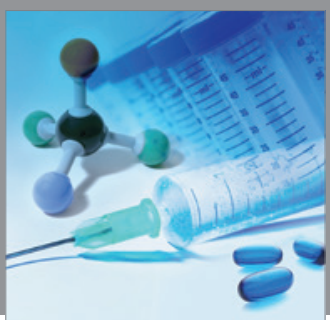

International Journal of

Medicinal Chemistry

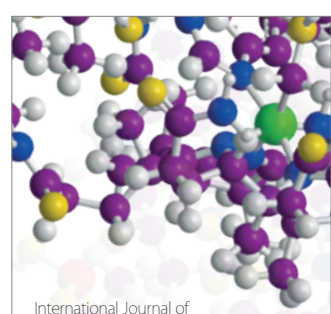

Carbohydrate Chemistry

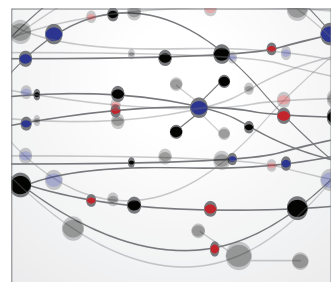

The Scientific World Journal
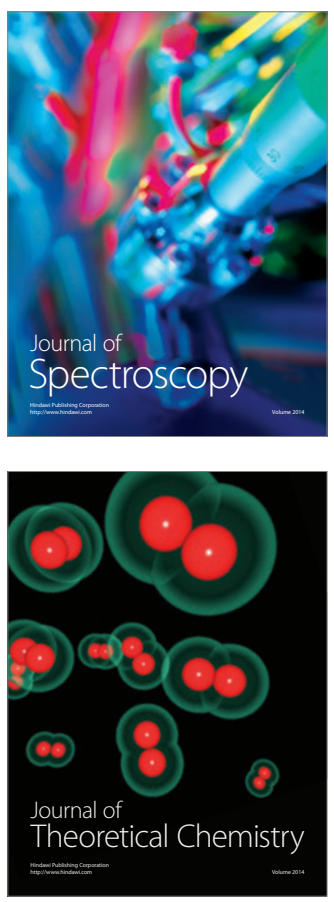
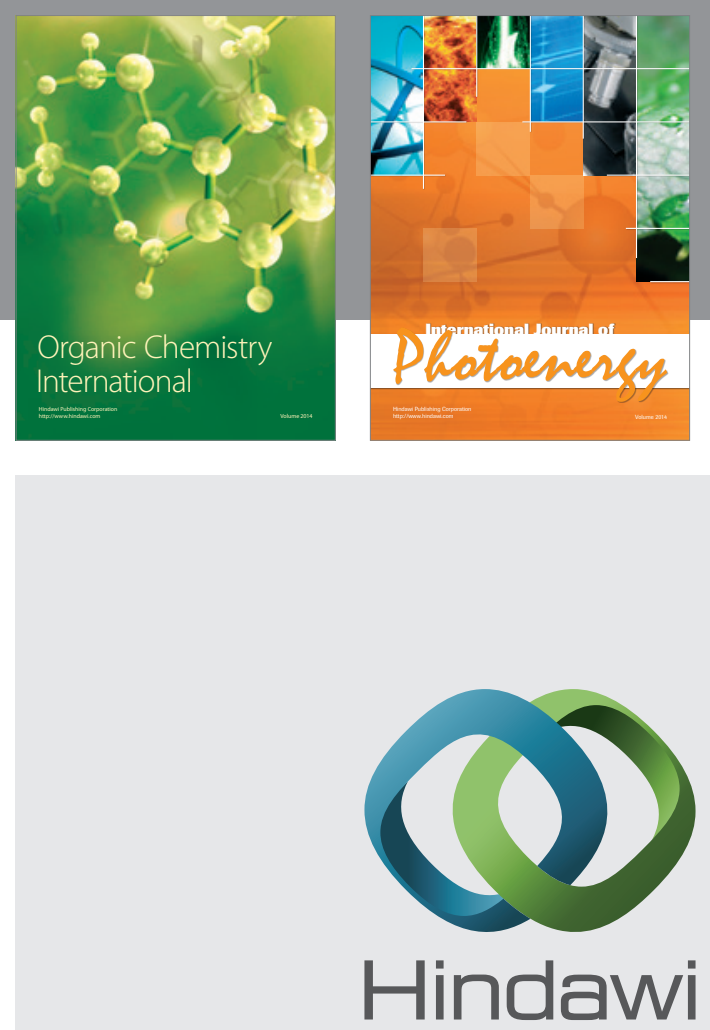

Submit your manuscripts at

http://www.hindawi.com
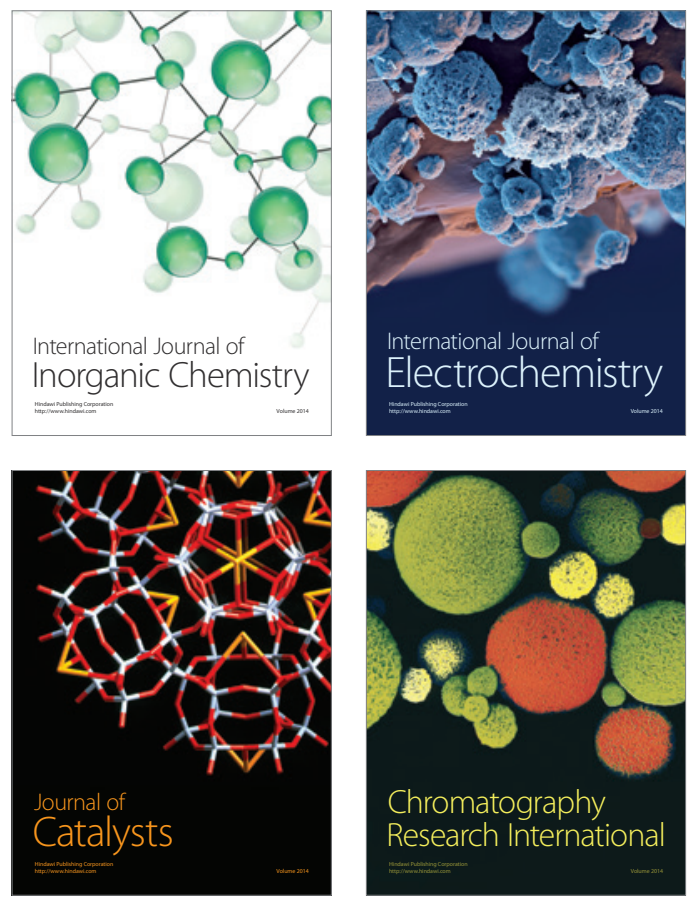
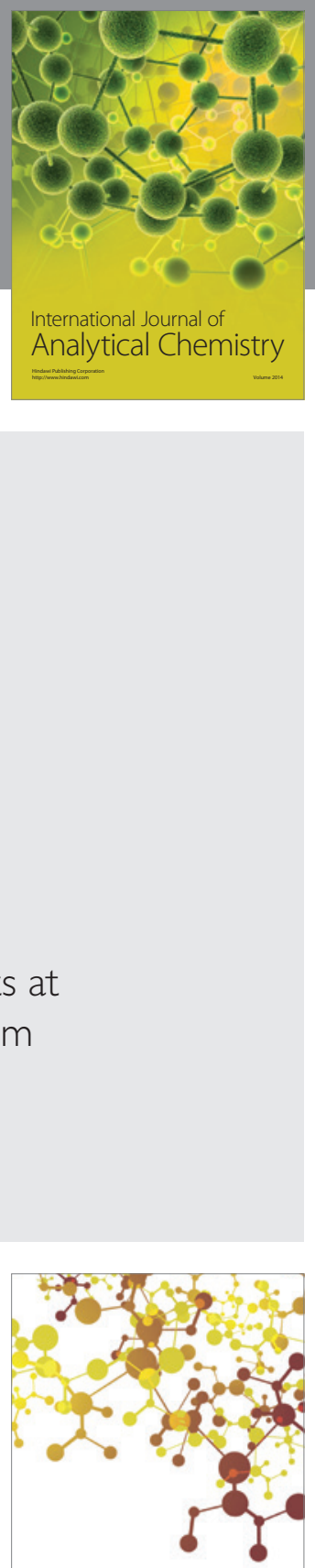

Journal of

Applied Chemistry
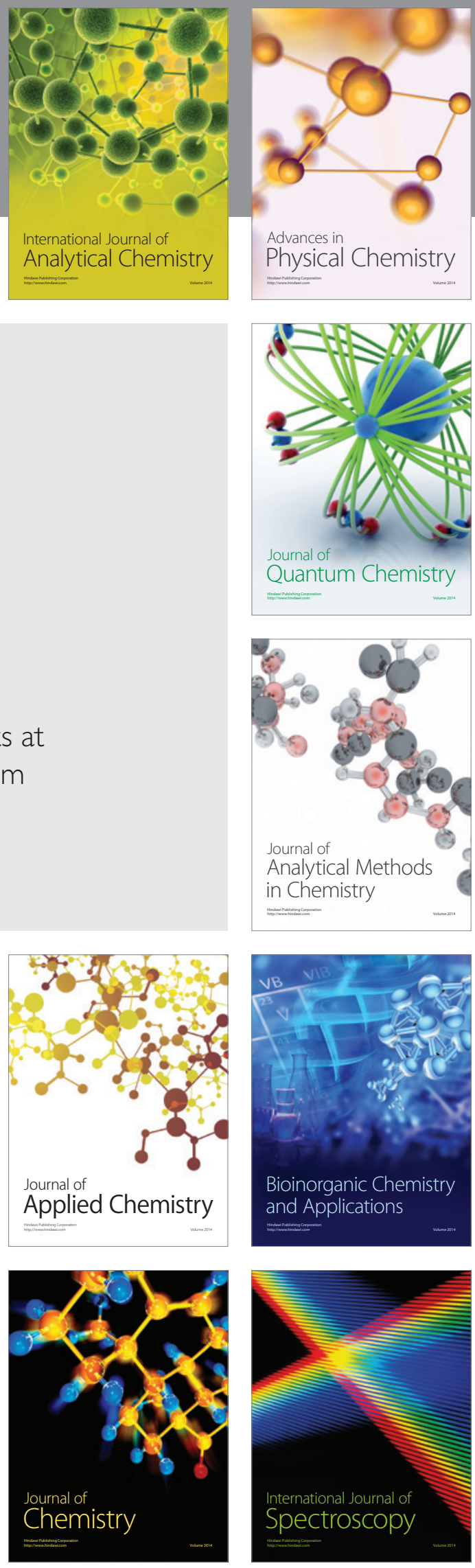